\title{
Penggunaan Teknologi Internet dalam Sistem Penjualan Online untuk Meningkatkan Kepuasan dan Pembelian Berulang Produk Batik pada Usaha Kecil dan Menengah di Jawa Timur
}

\author{
Muslichah Erma Widiana \\ Fakultas Ekonomi, Universitas Bhayangkara \\ Jl. Ahmad Yani 114 Surabaya 60231 \\ Email: widiandra08@yahoo.co.id \\ Henky Supit \\ Sri Hartini \\ Fakultas Ekonomi dan Bisnis, Universitas Airlangga \\ Jl. Airlangga 4-6 Surabaya 60286
}

\begin{abstract}
Abstrak
Usaha bisnis secara online tidak dapat dipisahkan dari aspek CRM. Strategi CRM dapat memperkaya pengetahuan produsen tentang customer, untuk memperbaiki dan mengkustomisasi interaksi dengan customer, sehingga tercipta hubungan jangka panjang. Penelitian ini bertujuan untuk menganalisa hubungan kausal dari penggunaan strategi CRM terhadap marketing outcomes. Teknik pengambilan sampel adalah cluster proporsional random sampling. Sampel diambil berdasarkan kelompok populasi konsumen produk batik online di UKM Jawa Timur, periode Juni-September 2010. Analisa data menggunakan SEM. Hasil menunjukkan keyakinan akan kemudahaan berpengaruh signifikan terhadap keyakinan akan kemanfaatan dan pembelian berulang, keyakinan akan kemanfaatan berpengaruh signifikan terhadap kepuasan dan pembelian berulang, serta kepuasan berpengaruh signifikan terhadap pembelian berulang.
\end{abstract}

Kata Kunci: Keyakinan akan Kemudahaan, Keyakinan akan Kemanfaatan, Kepuasan, Pembelian Berulang

\begin{abstract}
Online bussiness couldn't be seperated from CRM. CRM strategies could enhance producers' knowledge about their consumers, to improve and customize their interactions with their consumers, and will create a long-term a long term relationship. This paper aimed to analyze the causal effect of the use of strategic CRM on marketing outcomes. The selected sample is based on a group of online batik buyers on SMEs in East Java, for the period June-September 2010. Data analyzed using SEM. The results showed that percieved ease of use has a significant effect on perceived usefulness, satisfaction, and usage intention, percieved usefulness significantly affects satisfaction and usage intention, and satisfaction is significant for usage intention.
\end{abstract}

Keywords: Percieved Ease of Use, Percieved Usefulness, Satisfaction, Usage Intention

\section{PENDAHULUAN}

Penggunaan internet untuk bisnis secara online telah tumbuh dengan pesatnya. Total nilai perdagangan barang dan jasa dunia melalui e-commerce mencapai $\$ 4,3$ trilliun pada tahun 2004 . Tingkat pertumbuhan perdagangan via internet dari tahun 2001 hingga 2005 mencapai 68\% di Amerika Serikat, Eropa 91\%, dan Asia 109\%. Menariknya, 85\% dari perusahaan yang melibatkan perdagangan online tersebut adalah usaha berskala kecil dan menengah (Celuch et al., 2007). Strategi bisnis dengan menggunakan Customer Relationship Management (CRM) banyak terkait dengan strategi bisnis yang lain, seperti teknologi. Technology Acceptance Model (TAM) memberikan informasi atau hasil yang sangat umum saja tentang minat dan perilaku pemakai sistem dalam menerima sistem teknologi informasi. TAM hanya 
menjelaskan alasan mengapa pemakai menggunakan sistem, yaitu keyakinan akan kemudahan (perceived ease of use) dan keyakinan akan kemanfaatan (perceived usefulness).

Warisan budaya yang dimiliki Indonesia salah satunya adalah produk batik. Namun, batik Indonesia beberapa tahun terakhir menghadapi persaingan ketat dengan produksi dari sejumlah negara, seperti Malaysia, Thailand, Singapura, Afrika Selatan dan Polandia. Usaha kerajinan Batik Indonesia mencapai 48.287 unit dengan menyerap tenaga kerja 792.300 orang setara dengan nilai produksi Rp2,9 triliun dan nilai ekspor US $\$ 110$ juta berlokasi di 17 provinsi sebagai basis produksi. Batik merupakan warisan budaya Indonesia yang disahkan oleh UNESCO pada tanggal 2 Oktober 2009 dan di Indonesia tanggal 2 Oktober 2009 dicanangkan sebagai hari batik. Dengan menggunakan teknologi internet sebagai media pemasaran dengan menjalin hubungan secara jangka panjang dengan konsumen agar diperoleh kesesuaian antara pemasar dengan konsumen sehingga konsumen merasakan puas dan pemasar mendapatkan implikasinya, yaitu pembelian berulang (usage intention).

Penulis ingin mengkaji lebih mendalam pengaruh teknologi internet dalam sistem penjualan online untuk meningkatkan kepuasan (satisfaction) dan pembelian berulang produk batik pada Usaha Kecil dan Menengah (UKM) di Jawa Timur. Sejumlah masalah yang akan dikaji adalah mengenai keyakinan akan kemudahan dan pengaruhnya terhadap keyakinan akan kemanfaatan, keyakinan akan kemudahan dan pengaruhnya terhadap kepuasan, keyakinan akan kemudahan dan pengaruhnya terhadap pembelian berulang, keyakinan akan kemanfaatan dan pengaruhnya terhadap kepuasan, keyakinan akan kemanfaatan dan pengaruhnya terhadap pembelian berulang, kepuasan dan pengaruhnya terhadap pembelian berulang.

Penelitian ini dapat memberikan kontribusi terhadap pengembangan ilmu pengetahuan di bidang manajemen, khususnya teori-teori pemasaran yang menekankan bahwa melaksanakan strategi CRM dapat dilakukan dengan investasi teknologi dengan pengalokasian sumber daya organisasional ke dalam aktivitas pemasaran, sehingga dapat memberikan manfaat pada hubungan jangka panjang pada konsumen aktual dan potensial, terutama dalam mengidentifikasi faktor yang mempengaruhi Marketing Outcome (MO). Secara umum, penelitian ini diharapkan dapat memberikan informasi kepada organisasi atau perusahaan dalam menggunakan strategi pemasaran yang berkaitan dengan implementasi teknologi untuk keberlanjutan hubungan jangka panjang dengan konsumen. Bagi Usaha Kecil dan Menengah, implikasi penelitian ini dapat dikaitkan dengan aspek pemasaran dalam rangka meningkatkan MO, yaitu kepuasan dan pembelian berulang.

\section{LANDASAN TEORI}

\section{a. Customer Relationship Management}

CRM adalah proses mengidentifikasi pelanggan, menciptakan customer knowledge, membangun customer relationships, dan membentuk persepsi pelanggan terhadap organisasi serta solusinya (Srivastava \& Fahey, 1999). CRM merupakan strategi yang difasilitasi teknologi untuk mengubah keputusan berbasis data menjadi tindakan bisnis dalam rangka merespons dan mengantisipasi perilaku pelanggan aktual, merupakan dinamika perubahan strategis, proses, organisasional, dan teknis yang dilakukan organisasi dalam rangka mengelola perusahaannya secara lebih baik dan selaras dengan perilaku pelanggan (Brown, 2000).

\section{b. Technology Acceptance Model}

Tujuan utama TAM seperti yang dinyatakan oleh Davis (1989) adalah untuk menjelaskan faktor yang mempengaruhi dalam penerimaan teknologi informasi dengan jangkauan luas dari teknologi informasi dan populasi dari pengguna. Dalam TAM penggunaan sistem aktual ditentukan oleh perilaku niat dalam menggunakan, yang pada gilirannya ditentukan bersama dengan sikap terhadap penggunaan dan kegunaan yang dirasakan.

\section{Percieved Ease of Use}

Davis (1989) mendefinisikan percieved ease of use sebagai keyakinan akan kemudahan penggunaan, yaitu tingkat kepercayaan user bahwa teknologi atau sistem tersebut dapat digunakan dengan mudah dan bebas dari masalah. Intensitas penggunaan dan interaksi antara pengguna dengan sistem juga dapat menunjukkan kemudahan penggunaan. Davis (1989) memberikan beberapa indikator percieved ease of use: ease of learn, controllable, clear and understandable, flexible, ease to become skillful, ease to use.

\section{Percieved Usefulness}

Davis (1989) mendefinisikan perceived usefulness sebagai keyakinan akan kemanfaatan, yaitu tingkat kepercayaan user bahwa penggunaan teknologi atau sistem akan meningkatkan performa mereka 
dalam bekerja. Thompson \& Howell (1991) juga menyebutkan bahwa individu akan menggunakan teknologi informasi jika mengetahui manfaat positif atas penggunaannya. Davis (1989) memberikan beberapa indikator percieved usefulness, yaitu work more quickly, job performance, increase productivity, makes job easier, useful.

\section{c. Satisfaction}

Usmara (2003) menyatakan satisfaction adalah perbandingan antara kinerja yang diterima dengan standard perbandingan ekspektasi, ideal, pesaing, janji pemasar, dan norma. Satisfaction menurut Kotler (2002) adalah tingkat perasaan seseorang setelah membandingkan kinerja atau hasil yang ia rasakan dengan harapannya. Jadi pada dasarnya, satisfaction itu merupakan perbedaan antara harapan konsumen dengan kinerja aktual yang dirasakan. Indikator dalam satisfaction secara universal menurut Dutka (1995) adalah: attributes related to the product, attributes related to service, and attributes related to purchase.

\section{d. Usage Intention}

Definisi usage intention menurut Davis (1989) adalah kecenderungan perilaku untuk tetap menggunakan suatu teknologi dan keinginan untuk memotivasi pengguna lain. Dari penelitian penggunaan internet Gefen et al. (2003) mendefinisikan usage intention adalah niat penggunaan kembali terutama ditujukan pada individu untuk melakukan pembelian secara online melalui internet. Niat untuk selalu menggunakan online dalam pembelian dan merekomendasikan pembelian online (Cheng et al., 2005; Lin \& Hsieh, 2007). Cheng et al. (2005) mengembangkan indikator pembelian berulang sebagai berikut: selalu menggunakan internet banking untuk keperluan perbankan, menggunakan internet banking untuk menyelesaikan transaksi perbankan, saya menggunakan sendiri internet banking untuk menyelesaikan transaksi perbankan saya sendiri.

UKM dapat dijabarkan sebagai kegiatan ekonomi rakyat berskala kecil, baik yang bersifat informal, tradisional maupun semi modern. Bagi Negara Indonesia, rakyat bukan hanya sebagai indikator keberadaan negara, tetapi juga merupakan penegak kedaulatan yang menduduki tempat paling tinggi dalam konstitusi (UUD 1945). Keinginan untuk mensejahterakan semua rakyat juga merupakan amanat konstitusi dan oleh karena sebagian besar $(87,4 \%)$ rakyat Indonesia adalah kelompok UKM, maka pemberdayaan ekonomi rakyat dapat diidentikkan dengan pemberdayaan UKM.

\section{METODE PENELITIAN}

Penelitian ini dirancang sebagai penelitian explanatory, karena bertujuan untuk menjelaskan pengaruh hubungan-hubungan sebab dan akibat diantara variabel-variabel didalam permasalahan penelitian yang telah diidentifikasi secara jelas (Zigmund, 1997). Jenis data pada penelitian ini adalah data crosssection, yaitu pengambilan data pada waktu tertentu bukan jangka panjang (longitudinal). Berdasarkan model penelitian yang dibangun, maka pendekatan

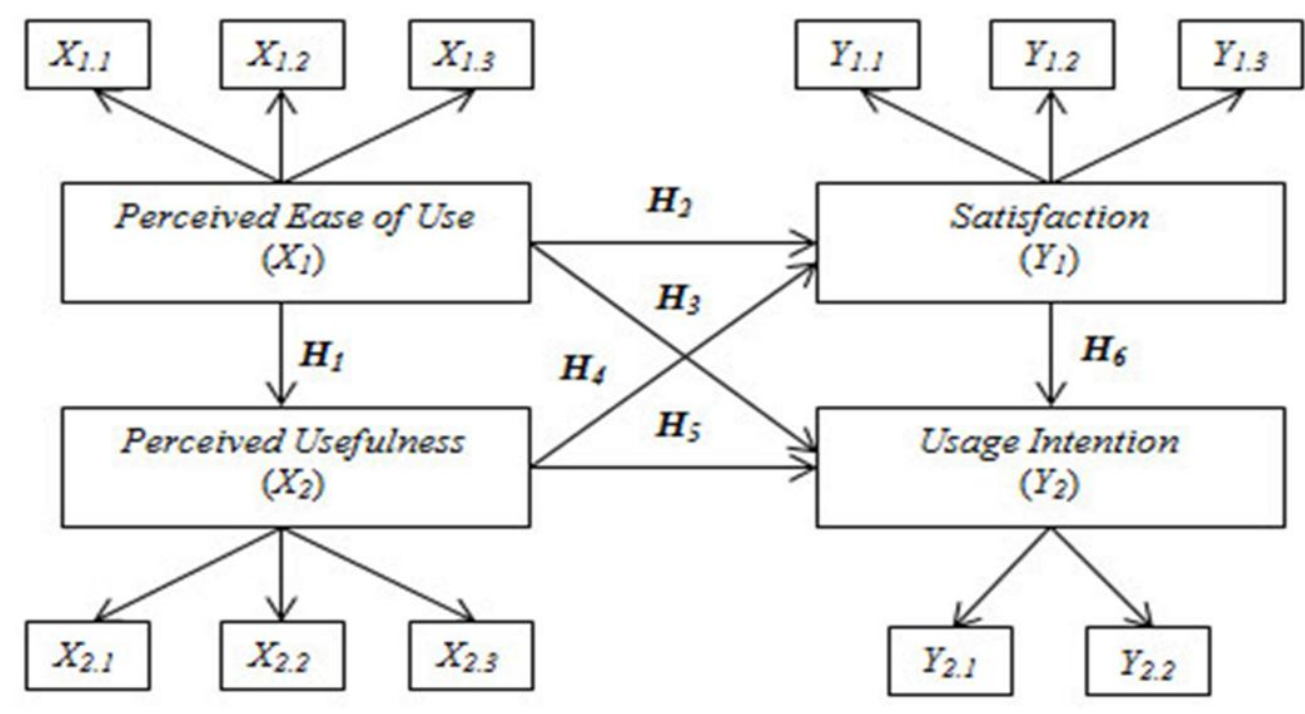

Gambar 1. Kerangka Konseptual 
analisisnya adalah multivariate, dengan empat variabel laten dan 11 indikator. Dalam penelitian ini jumlah indikatornya adalah 11 dan perkaliannya antara 5-10, di dalam penelitian ini mengambil perkalian 10. Berarti ukuran sampel yang akan digunakan dalam penelitian ini adalah $10 \times 11=110$ konsumen pembeli produk batik online di UKM Jawa Timur. Kriteria-kriteria responden adalah konsumen membeli secara online ke UKM yang memproduksi batik, membeli lebih dari satu kali di UKM. Keempat belas UKM online tersebut memiliki situs sendiri-sendiri, baik itu yang dikelola secara professional dengan meng-upgrade produk yang ditawarkan, melakukan promosi penjualan, maupun yang dikelola tidak begitu profesional, namun semuanya dapat melayani penjualan secara online.

Teknik pengambilan sampel yang digunakan dalam penelitian ini adalah proporsional random sampling. Sampel yang diambil berdasarkan kelompok populasi konsumen pembeli produk batik online di UKM Jawa Timur periode bulan Juni-September 2010 di Kabupaten Sidoarjo, Jombang, Malang, Bangkalan, Surabaya, dan Pamekasan.
Jumlah sampel ditentukan berdasarkan rumus:

$n_{i}=\frac{N i}{N} \times n$

Variabel-variabel dalam penelitian ini dikenal sebagai variabel laten, yang diklasifikasikan sebagai: variabel eksogen yang diukur oleh keyakinan akan kemudahan $\left(X_{I}\right)$ dan variabel endogen yang terdiri dari variabel endogen intervening dan diukur oleh keyakinan akan kemanfaatan $\left(X_{2}\right)$ dan kepuasan $\left(Y_{1}\right)$, serta variabel endogen tergantung yang diukur oleh pembelian berulang $\left(Y_{2}\right)$.

Instrumen Penelitian adalah kuesioner. Sebelum kuesioner disampaikan kepada responden sebanyak jumlah sampel penelitian, perlu dilakukan uji terhadap kuesioner, yaitu uji validitas dan reliabilitas. Tujuannya adalah untuk mengetahui apakah alat ukur (kuesioner) tersebut telah memiliki kemampuan untuk mengukur apa yang hendak diukur.

Teknik Analisis Data yang digunakan untuk menjawab hipotesis dalam penelitian ini menggunakan Structural Equation Modeling (SEM), dengan menggunakan paket program Amos 7,0 dan SPSS

Tabel 1. Perhitungan Jumlah Sampel Secara Proporsional

\begin{tabular}{llccc}
\hline \multicolumn{1}{c}{ Kabupaten } & \multicolumn{1}{c}{ UMKM } & Populasi & $\boldsymbol{n}_{\boldsymbol{i}}=\frac{\boldsymbol{N i}}{\boldsymbol{N}} \boldsymbol{x} \boldsymbol{n}$ & Sampel \\
\hline Sidoarjo & Batik Azizah & 186 & 6,95 & 7 \\
& Batik Sari Kenongo & 287 & 10,72 & 11 \\
& Batik Kusuma Share & 241 & 9 & 9 \\
& Kenongo & 176 & 6,58 & 7 \\
\hline Jombang & Sekar Jati Star & 248 & 9,27 & 9 \\
\hline Malang & Boos Batik & 321 & 11,99 & 12 \\
\hline Bangkalan & Pesona Batik Madura & 138 & 5,15 & 6 \\
\hline Surabaya & Moya Zham Shop & 167 & 6,24 & 7 \\
& Djoeragan Batik & 194 & 7,25 & 6 \\
& Batik Dewi saraswati & 149 & 5,56 & 7 \\
& Pramudya & 192 & 7,17 & 4 \\
\hline Pamekasan & Omah Batik & 99 & 3,70 & 8 \\
& Mandora & 231 & 8,63 & 12 \\
\hline
\end{tabular}

Tabel 2. Variabel Dan Indikator Penelitian

\begin{tabular}{llcc}
\hline \multicolumn{1}{c}{ Variabel } & \multicolumn{1}{c}{ Indikator } & Jumlah butir & \multicolumn{1}{c}{ Literatur pendukung } \\
\hline Perceived ease of use $\left(X_{I}\right)$ & Mudah dan jelas $\left(X_{1.1}\right)$ & 4 & Davis (1989), Hong et al. $(2006)$ \\
& Kontrol $\left(X_{1.2}\right)$ & 2 & \\
& Fleksibel $\left(X_{1.3}\right)$ & 2 & \\
\hline Perceived of usefulness $\left(X_{2}\right)$ & Efektif $\left(X_{2.1}\right)$ & 3 & Davis (1989), Hong et al $(2006)$ \\
& Bermanfaat $\left(X_{2.2}\right)$ & 2 & \\
& Efisien $\left(X_{2.3}\right)$ & 2 & \\
\hline Satisfaction $\left(Y_{1}\right)$ & Attributes related to the product $\left(Y_{1.1}\right)$ & 7 & Thorsten et al. (2002), Rebecca et \\
& Attributes related to service $\left(Y_{1.2}\right)$ & 3 & al. (2003), Hong et al (2006), \\
& Attributes related to purchase $\left(Y_{1.3}\right)$ & 3 & \\
\hline Usage intention $\left(Y_{2}\right)$ & Niat Penggunaan Kembali $\left(Y_{2.1}\right)$ & 3 & Davis $(1989)$ \\
& Rekomendasi $\left(Y_{2.2}\right)$ & 3 & \\
\hline
\end{tabular}


versi 15.0. Untuk mengestimasi hubungan saling ketergantungan secara simultan (Hair et al., 1998). Statistik inferensi dilakukan dengan melihat nilai probabilitas error pada setiap jalurnya. Jika nilai prob < 0,05 maka hipotesis tersebut diterima, sebaliknya jika prob $>0,05$ maka hipotesis ditolak.

\section{HASIL PENELITIAN DAN PEMBAHASAN}

Pada tahap awal dilakukan uji validitas dan reliabilitas pada item di setiap variabel penelitian. Hasilhasil uji validitas dan reliabilitas disajikan pada Tabel 3 sampai dengan Tabel 6.

Tabel 3. Uji Validitas dan Reliabilitas Perceived Ease of

\begin{tabular}{|c|c|c|c|}
\hline \multicolumn{4}{|c|}{ Use $\left(X_{I}\right)$} \\
\hline Item & Korelasi & Prob & Keterangan \\
\hline \multicolumn{4}{|c|}{ berbelanja secara online mudah dan jelas $\left(X_{I . I}\right)$} \\
\hline$X_{1 . l .1}$ & 0,7584 & $6,429 \cdot 10^{-035}$ & Valid \\
\hline$X_{1.1 .2}$ & 0,7972 & $7,298.10^{-041}$ & \\
\hline$X_{1.1 .3}$ & 0,8032 & $6,690.10^{-042}$ & \\
\hline$X_{1.1 .4}$ & 0,7402 & $1,662.10^{-032}$ & \\
\hline \multicolumn{4}{|c|}{ berbelanja secara online berfungsi sebagai pengontrol $\left(X_{I .2}\right)$} \\
\hline$X_{121}$ & 0,5950 & $1,287.10^{-018}$ & Valid \\
\hline$X_{1,2.2}$ & 0,7350 & $7,541.10^{-032}$ & \\
\hline \multicolumn{4}{|c|}{ berbelanja secara online fleksibel $\left(X_{l .3}\right)$} \\
\hline$X_{131}$ & 0,6962 & $2,029.10^{-027}$ & Valid \\
\hline$X_{1.3 .2}$ & 0,7032 & $3,618.10^{-028}$ & \\
\hline Reliabilitas & & & Reliabel \\
\hline
\end{tabular}

Tabel 4. Uji Validitas dan Reliabilitas Perceived Useful-

\begin{tabular}{|c|c|c|c|}
\hline Item & Korelasi & Prob & Keterangan \\
\hline \multicolumn{4}{|c|}{ pembelanjaan online efektif $\left(X_{2.1}\right)$} \\
\hline$X_{2.1 .1}$ & 0,6833 & $4,176.10^{-026}$ & \multirow[t]{3}{*}{ Valid } \\
\hline$X_{2.1 .2}$ & 0,8092 & $5,799.10^{-043}$ & \\
\hline$X_{2.1 .3}$ & 0,7053 & $2,131.10^{-028}$ & \\
\hline \multicolumn{4}{|c|}{ pembelanjaan online bermanfaat $\left(X_{2.2}\right)$} \\
\hline$X_{2.2 .1}$ & 0,7223 & $2,519.10^{-030}$ & \multirow[t]{2}{*}{ Valid } \\
\hline$X_{2.2 .2}$ & 0,7530 & $3,532.10^{-034}$ & \\
\hline \multicolumn{4}{|c|}{ pembelanjaan online efisien $\left(X_{2.3}\right)$} \\
\hline$X_{2.3 .1}$ & 0,6328 & $1,573.10^{-021}$ & \multirow[t]{2}{*}{ Valid } \\
\hline$X_{2.3 .2}$ & 0,6487 & $7,125.10^{-023}$ & \\
\hline Reliabilitas & & & Reliabel \\
\hline
\end{tabular}

Berdasarkan Tabel 3, dapat dijelaskan sebagai berikut: nilai probabilitas keempat item pembentuk berbelanja secara online mudah dan jelas lebih kecil dari taraf signifikansi $(\alpha)=0,05$. Hal ini berarti bahwa keempat item tersebut valid dan dapat digunakan un tuk mengukur indikator berbelanja secara online mudah dan jelas. Nilai probabilitas kedua item pembentuk berbelanja secara online berfungsi sebagai pengontrol lebih kecil dari taraf signifikansi $(\alpha)=$ 0,05 . Hal ini berarti bahwa kedua item tersebut valid. Jadi, kedua item tersebut dapat digunakan untuk men- gukur indikator berbelanja secara online berfungsi sebagai pengontrol. Nilai probabilitas kedua item pembentuk berbelanja secara online fleksibel lebih kecil dari taraf signifikansi $(\alpha)=0,05$. Hal ini berarti bahwa kedua item tersebut valid. Jadi, kedua item tersebut dapat digunakan untuk mengukur indikator berbelanja secara online fleksibel.

Tabel 5. Uji Validitas dan Reliabilitas Satisfaction $\left(Y_{I}\right)$

\begin{tabular}{|c|c|c|c|}
\hline Item & Korelasi & Prob & Keterangan \\
\hline \multicolumn{4}{|c|}{ attributes related to the product $\left(Y_{l . l}\right)$} \\
\hline$Y_{1.1 .1}$ & 0,6745 & $3,100.10^{-025}$ & \multirow[t]{7}{*}{ Valid } \\
\hline$Y_{1.1 .2}$ & 0,6846 & $3,134 \cdot 10^{-026}$ & \\
\hline$Y_{1.1 .3}$ & 0,6955 & $2,403.10^{-027}$ & \\
\hline$Y_{1.1 .4}$ & 0,7268 & $7,557.10^{-031}$ & \\
\hline$Y_{1.1 .5}$ & 0,6850 & $2,865 \cdot 10^{-026}$ & \\
\hline$Y_{1.1 .6}$ & 0,7994 & $3,006.10^{-041}$ & \\
\hline$Y_{1.1 .7}$ & 0,6522 & $3,530 \cdot 10^{-223}$ & \\
\hline \multicolumn{4}{|c|}{ attributes related to service $\left(Y_{1.2}\right)$} \\
\hline$Y_{1.2 .1}$ & 0,7225 & $2,407.10^{-130}$ & \multirow[t]{3}{*}{ Valid } \\
\hline$Y_{1.2 .2}$ & 0,7529 & $3,657 \cdot 10^{-034}$ & \\
\hline$Y_{1.2 .3}$ & 0,7022 & $4,638.10^{-028}$ & \\
\hline \multicolumn{4}{|c|}{ attributes related to purchase $\left(Y_{1.3}\right)$} \\
\hline$Y_{1.3 .1}$ & 0,7121 & $3,750.10^{-029}$ & \multirow[t]{3}{*}{ Valid } \\
\hline$Y_{1,3,2}$ & 0,7662 & $5,138.10^{-036}$ & \\
\hline$Y_{1.3 .3}$ & 0,7505 & $7,495.10^{-034}$ & \\
\hline Reliabilitas & \multicolumn{2}{|c|}{0,9207} & Reliabel \\
\hline
\end{tabular}

Tabel 6. Uji Validitas dan Reliabilitas Usage Intention

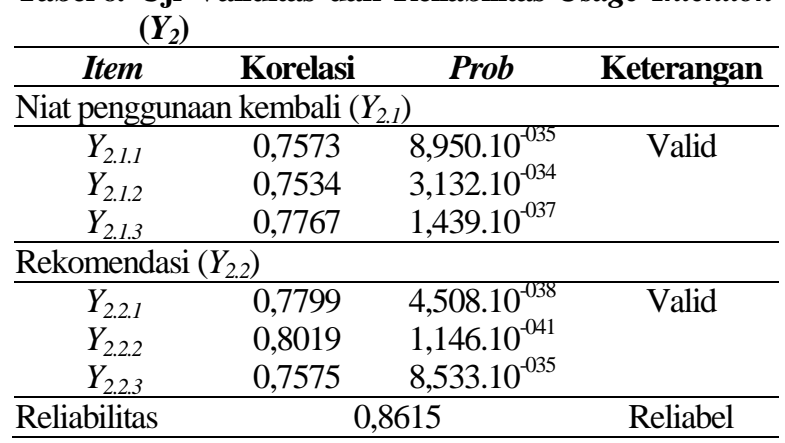

Berdasarkan Tabel 4 dapat dijelaskan sebagai berikut: nilai probabilitas ketiga item pembentuk pembelanjaan online efektif lebih kecil dari taraf signifikansi $(\alpha)=0,05$. Hal ini berarti bahwa ketiga item tersebut valid. Jadi, ketiga item tersebut dapat digunakan untuk mengukur indikator pembelanjaan online efektif. Nilai probabilitas kedua item pembentuk pembelanjaan online bermanfaat lebih kecil dari taraf signifikansi $(\alpha)=0,05$. Hal ini berarti bahwa kedua item tersebut valid. Jadi, kedua item tersebut dapat digunakan untuk mengukur indikator pembelanjaan online bermanfaat. Nilai probabilitas kedua item pembentuk pembelanjaan online efisien lebih kecil dari taraf signifikansi $(\alpha)=0,05$. Hal ini berarti bahwa kedua item tersebut valid. Jadi, kedua item tersebut dapat digunakan untuk mengukur indikator pembelanjaan online efisien. 
Berdasarkan Tabel 5 dapat dijelaskan sebagai berikut: nilai probabilitas tujuh item pembentuk indikator attributes related to the product lebih kecil dari taraf signifikansi $(\alpha)=0,05$. Hal ini berarti bahwa tujuh item tersebut valid. Jadi, tujuh item tersebut dapat digunakan untuk mengukur indikator attributes related to the product. Nilai probabilitas tiga item pembentuk indikator attributes related to service lebih kecil dari taraf signifikansi $(\alpha)=0,05$. Hal ini berarti bahwa tiga item tersebut valid. Jadi, tiga item tersebut dapat digunakan untuk mengukur indikator attributes related to service. Nilai probabilitas tiga item pembentuk indikator attributes related to purchase lebih kecil dari taraf signifikansi $(\alpha)=0,05$. Hal ini berarti bahwa tiga item tersebut valid. Jadi, tiga item tersebut dapat digunakan untuk mengukur indikator attributes related to purchase.

Berdasarkan Tabel 6 dapat dijelaskan sebagai berikut: nilai probabilitas tiga item pembentuk indikator niat penggunaan kembali lebih kecil dari taraf signifikansi $(\alpha)=0,05$. Hal ini berarti bahwa tiga item tersebut valid. Jadi, tiga item tersebut dapat digunakan untuk mengukur indikator niat penggunaan kembali. Nilai probabilitas tiga item pembentuk indikator rekomendasi lebih kecil dari taraf signifikansi $(\alpha)=0,05$. Hal ini berarti bahwa tiga item tersebut valid. Jadi, tiga item tersebut dapat digunakan untuk mengukur indikator rekomendasi.
Uji hipotesis dilakukan dengan melihat koefisien jalur dan nilai $p_{\text {value }}$ pada tingkat signifikansi 0,05 . Hasil selengkapnya disajikan pada Tabel 7. Berdasarkan Tabel 7 dan Gambar 2, maka diperoleh hasil pengujian hipotesis sebagai berikut:

\section{Keyakinan akan Kemudahan dan Keyakinan akan Kemanfaatan}

Hasil penelitian ini menyatakan bahwa keyakinan akan kemudahan berpengaruh signifikan terhadap keyakinan akan kemanfaatan, karena nilai critical ratio 7,478 lebih besar dari 1,96. Hal ini berarti semakin tinggi keyakinan akan kemudahan maka semakin tinggi pula keyakinan akan kemanfaatan. Hasil penelitian ini mendukung hasil penelitian Davis (1989) menyatakan penggunaan sistem tersebut meningkatkan efektivitas kerja dan memberikan kemudahan dalam penggunaan. Berdasarkan hasil penelitian ini, penggunaan sistem penjualan online disertai dengan prosedur cara berbelanja sampai proses pembayaran dapat memberikan kemudahan bagi konsumen untuk mengoperasionalkan website yang disediakan oleh toko batik.

Hasil penelitian ini mendukung hasil penelitian terdahulu yang dilakukan oleh Rao \& Throshani (2007) yang menyatakan bahwa kemudahan menggunakan layanan mobile technology setiap harinya

Tabel 7. Pengujian Hipotesis Hasil Model Persamaan Struktural pada Konsumen yang Berbelanja Secara Online di Website Toko Batik di Jawa Timur Tahun 2011

\begin{tabular}{|c|c|c|c|c|}
\hline Hipotesis & $\begin{array}{l}\text { Koefisien } \\
\text { Jalur }\end{array}$ & C.R. & $p_{\text {value }}$ & Hasil Pengujian Hipotesis \\
\hline $\begin{array}{l}\text { Perceived ease of use }\left(X_{1}\right) \text { terhadap Perceived } \\
\text { usefulness }\left(X_{2}\right)\end{array}$ & 0.563 & 7.478 & 0.000 & $\boldsymbol{H}_{\boldsymbol{I}}=$ arah positif dan berpengaruh signifikan \\
\hline $\begin{array}{l}\text { Perceived ease of use }\left(X_{1}\right) \text { terhadap Satisfaction } \\
\left(Y_{1}\right)\end{array}$ & 0.042 & 2.651 & 0.009 & $\boldsymbol{H}_{2}=$ arah positif dan berpengaruh signifikan \\
\hline $\begin{array}{l}\text { Perceived ease of use }\left(X_{1}\right) \text { terhadap Usage Inten- } \\
\text { tion }\left(Y_{2}\right)\end{array}$ & 0.122 & 3.259 & 0.004 & $\boldsymbol{H}_{3}=$ arah positif dan berpengaruh signifikan \\
\hline $\begin{array}{l}\text { Perceived usefulness }\left(X_{2}\right) \text { terhadap Satisfaction } \\
\left(Y_{1}\right)\end{array}$ & 0.078 & 2.853 & 0.007 & $\boldsymbol{H}_{4}=$ arah positif dan berpengaruh signifikan \\
\hline $\begin{array}{l}\text { Perceived usefulness }\left(X_{2}\right) \text { terhadap Usage Inten- } \\
\text { tion }\left(Y_{2}\right)\end{array}$ & 0.453 & 4.194 & 0.000 & $\boldsymbol{H}_{5}=$ arah positif dan berpengaruh signifikan \\
\hline Satisfaction $\left(Y_{1}\right)$ terhadap Usage Intention $\left(Y_{2}\right)$ & 0.786 & 5.445 & 0.000 & $\boldsymbol{H}_{6}=$ arah positif dan berpengaruh signifikan \\
\hline
\end{tabular}

\begin{tabular}{|c|c|c|c|c|}
\hline \multicolumn{2}{|c|}{$\begin{array}{l}\text { Perceived Ease of Use } \\
\qquad\left(X_{1}\right)\end{array}$} & $C R=2,651(\mathrm{~s})$ & \multicolumn{2}{|c|}{$\begin{array}{c}\text { Satisfaction } \\
\left(Y_{1}\right)\end{array}$} \\
\hline $\begin{array}{c}\beta_{1}=0,563 \\
C R=7,478(\mathrm{~s})\end{array}$ & $\begin{aligned} \beta_{3} & = \\
C R & =\end{aligned}$ & & & $\begin{array}{c}\beta_{6}=0,786 \\
C R=5,445(\mathrm{~s})\end{array}$ \\
\hline \multicolumn{2}{|c|}{$\begin{array}{l}\text { Perceived Usefulness } \\
\qquad\left(X_{2}\right)\end{array}$} & & \multicolumn{2}{|c|}{$\begin{array}{l}\text { Usage Intention } \\
\qquad\left(Y_{2}\right)\end{array}$} \\
\hline
\end{tabular}

Gambar 2. Hasil Analisis Model Persamaan Struktural 
meningkatkan kemanfatan untuk browsing internet melalui fasilitas yang disediakan oleh mobile technology. Berdasarkan hasil penelitian ini, responden juga memanfaatkan handphone untuk melakukan pembelanjaan online, karena teknologi terkini setiap handphone sudah menyediakan layanan opera mini untuk melakukan browsing. Apalagi dengan adanya Blackberry atau handphone berteknologi android akan semakin membuktikan bahwa kemudahan yang difasilitasi oleh teknologi informasi akan semakin meningkatkan kemanfaatan bagi konsumen dalam melakukan pembelanjaan online.

Chin \& Todd (1995) teknologi informasi menjadikan pekerjaan lebih mudah, mempertinggi efektivitas, mengembangkan kinerja pekerjaan. Kemudahan mempelajari dan kejelasan prosedur belanja secara online akan memberikan manfaat pada konsumen untuk dapat menemukan produk batik yang terbaik. Berdasarkan teori CRM pengaruh keyakinan akan kemudahan terhadap keyakinan akan kemanfaatan masuk dalam lingkup kajian operasional yaitu otomatisasi pemasaran dalam pemanfaatan teknologi pada proses-proses pemasaran dengan cara memudahkan para pemakainya mengeksplorasi data tentang pelanggan untuk menjalin komunikasi dan memberikan penawaran kepada pelanggan potensial.

\section{Keyakinan akan Kemudahan dan Kepuasan}

Hasil penelitian ini menyatakan bahwa keyakinan akan kemudahan berpengaruh signifikan terhadap kepuasan, karena nilai critical ratio 2,651 lebih besar dari 1,96. Hasil penelitian ini mendukung hasil penelitian Lin \& Sun (2009) dan Hong et al. (2006). Keyakinan akan kemudahan berpengaruh terhadap kepuasan konsumen yang melalukan pembelanjaan online. Kemudahan dalam mengoperasionalkan teknologi untuk melakukan pembelanjaan online menjadikan konsumen puas. Salah satu peraturan penting yang harus diingat oleh toko online adalah bahwa toko online masih berurusan dengan pelanggan. Apa yang memuaskan pelanggan dalam lingkungan offline juga akan memuaskan pelanggan pada waktu online. Terlalu sering, toko online terlampau terpikat pada internet dan kemampuan teknisnya, sehingga lupa bahwa toko online berurusan dengan orang yang sama yang dilayani secara offline. Toko online mendelegasikan tanggung jawab untuk pengembangan dan pengelolaan websitenya pada staf teknis yang terfokus pada teknologi bukan pada pelanggan. Hasilnya adalah bahwa pelanggan seringkali terlupakan. Perusahaan yang beroperasi diinternet harus memahami psikologi pelanggan. Sebuah website tidak hanya harus indah dipandang secara teknis, tetapi juga mudah digunakan. Situs tersebut harus mengurangi rasa frustasi pelanggan dan menyediakan dorongan positif bagi keputusan pelanggan untuk berhubungan dengan perusahaan.

Berdasarkan teori CRM, pengaruh keyakinan akan kemudahan terhadap kepuasan merupakan aplikasi lingkup CRM operasional dan analitis yaitu dapat memberikan solusi yang lebih tepat waktu, bahkan bersifat amat personal bagi segala permasalahan konsumen, sehingga semakin meningkatkan kepuasan mereka. Untuk memberikan solusi yang lebih cepat dan personal, toko batik online menyediakan fasilitas hubungi kami atau contact us. Para pelanggan dengan mendaftar terlebih dahulu dapat menuliskan kepuasan yang diterima maupun ketidakpuasan atas layanan yang diberikan oleh perusahaan (testimoni). Kepuasan atau ketidakpuasan akan ditanggapi secara personal dengan mengirimkan e-mail kepada pelanggan masing-masing.

\section{Keyakinan akan Kemudahan dan Pembelian Berulang}

Hasil penelitian ini menyatakan bahwa keyakinan akan kemudahan berpengaruh signifikan terhadap pembelian berulang, karena nilai critical ratio 3,259 lebih besar dari 1,96. Hasil penelitian ini mendukung hasil penelitian Hong et al. (2006) keyakinan akan kemudahan mempengaruhi penggunanya untuk lebih kontinu dan lebih meningkatkan penggunaan internet dimasa mendatang Cheng et al. (2005) membuktikan bahwa kemudahan yang diperoleh nasabah ketika menggunakan internet banking dapat meningkatkan intensitas penggunaan internet banking untuk menyelesaikan transaksi keuangannya. Lin \& Sun (2009) membuktikan adanya pengaruh keyakinan akan kemudahan terhadap pembelian berulang.

Kemudahan berbelanja yang disediakan dalam tuntunan belanja mendorong konsumen untuk menambah jumlah pembelian dan memasukkan ke dalam keranjang belanja yang ada di sisi kanan. Demikian juga tampilan produk best seller yang diletakkan di bawah keranjang belanja memberikan kemudahan konsumen untuk mencari produk yang sering dibeli oleh konsumen dan tinggal menarik (drag) ke atas untuk dimasukkan ke dalam keranjang belanja. Upaya ini dilakukan untuk mendorong usage intention sering mungkin, sehingga diharapkan konsumen dapat membeli lebih dari satu produk sekali berkunjung.

Kemudahan penggunaan teknologi internet untuk pembelian online dapat digunakan untuk menjaring kelompok pelanggan yang memberikan keuntungan terbesar kepada perusahaan. Kelompok 
ini selalu membeli dalam jumlah yang besar dan frekuensi pembeliannya tinggi. Mereka tidak sensitif terhadap harga, tidak segan mengeluarkan uang untuk sesuatu yang hanya bisa dinikmati pada masa yang akan datang, mau mencoba produk yang baru yang ditawarkan oleh perusahaan dan yang paling penting memiliki komitmen untuk tidak berpaling kepada pesaing. Untuk menjaring kelompok pelanggan seperti yang dijelaskan di atas, maka perusahaan harus menjalankan langkah-langkah: siap memberikan layanan terbaik yang dimiliki, siap dan responsif memberikan layanan purna jual terbaik, siap lebih proaktif memonitor perubahan yang terjadi di pasar dan memberikan yang terbaik untuk memenuhi kebutuhan yang unik.

\section{Keyakinan akan Kemanfaatan dan Kepuasan}

Hasil penelitian ini menyatakan bahwa keyakinan akan kemanfaatan berpengaruh signifikan terhadap kepuasan, karena nilai critical ratio 2,853 lebih besar dari 1,96. Hal ini dapat diartikan peningkatan keyakinan akan kemanfaatan berpengaruh pada peningkatan kepuasan. Hasil penelitian ini mendukung hasil penelitian Lin \& Sun (2009). Hong et al. (2006) membuktikan bahwa keyakinan akan kemanfaatan berpengaruh terhadap kepuasan penggunaan mobile internet. Konsumen yang menggunakan mobile internet menyatakan bahwa hidup menjadi lebih mudah dengan adanya mobile internet dan sangat bermanfaat bagi kehidupan mereka, karena mobile internet bermanfaat maka konsumen merasa senang dan puas.

Penyediaan menu detail produk oleh 78 ook batik online sangat bermanfaat bagi konsumen untuk memilih warna produk batik dan mengetahui bahan serta motif batiknya. Dengan menu detail, dapat mengevaluasi produk, sehingga dia mendapat barang terbaik yang merupakan harapan semua konsumen, dengan harapan terpenuhi maka dia akan puas. Hal ini akan meningkatkan kepuasan konsumen dalam berbelanja online, yaitu kepuasan dalam melakukan pilihan produk batik yang ditawarkan dan kepuasan dalam menentukan corak dan warna produk batik.

Internet memang memungkinkan pelanggan untuk mengakses produk atau jasa inti yang dibutuhkan. Internet juga memberikan layanan pendukung dengan memampukan pelanggan mengakses informasi, mentransfer dana atau pembelian produk. Internet pada umumnya juga memampukan pelayanan yang diberikan secara efisien dan cepat, pelayanan tersebut juga akurat secara teknis. Internet menciptakan nilai dalam bentuk akses dan kenyamanan. Kepuasan pelanggan melalui pemberian sejumlah manfaat kepada pelanggan secara online dapat di- pastikan dengan dukungan layanan seperti konfirmasi pemesanan, ketersediaan inventaris, memberikan informasi pelanggan tentang kondisi stok barang, memberitahukan biaya pengiriman sebelumnya.

\section{Keyakinan akan Kemanfaatan dan Pembelian Berulang}

Hasil penelitian ini menyatakan bahwa keyakinan akan kemanfaatan berpengaruh signifikan terhadap usage intention, karena nilai critical ratio 4,194 lebih besar dari 1,96. Hal ini dapat diartikan bahwa semakin tinggi keyakinan akan kemanfaatan maka semakin tinggi pula pengaruhnya terhadap pembelian berulang. Hasil penelitian ini mendukung hasil penelitian Hong et al. (2006) dan Rose \& Fogarty (2006), menggunakan mobile internet membantu mempercepat penyelesaian pekerjaan dapat mempengaruhi penggunanya untuk lebih kontinyu dan lebih meningkatkan penggunaan mobile internet di masa mendatang.

Berbelanja secara online efektif karena ada penghematan biaya tanpa harus berkunjung secara langsung, apalagi disediakan link ke facebook sebagai social media memberikan manfaat kepada konsumen untuk mempersingkat waktu dalam merekomendasikan pembelian batik online kepada teman-teman, keluarga dan menceritakan seputar produk batik yang sudah dibelinya. Komunikasi merupakan proses penting dalam pertukaran informasi antara pelanggan dengan perusahaan, pelangggan sebagai pengambil keputusan dalam proses pembelian memiliki kunci penting terjadinya komunikasi ini, bila komunilkasi dapat dilakukan antara kedua belah pihak, maka keduanya akan saling memahami apa yang menjadi kebutuhan dan harapan mereka.

\section{Kepuasan dan Pembelian Berulang}

Hasil penelitian ini menyatakan bahwa kepuasan berpengaruh signifikan terhadap pembelian berulang, karena nilai critical ratio 5,445 lebih besar dari 1,96 . Hal ini dapat diartikan semakin tinggi kepuasan semakin tinggi pula pembelian berulang. Kepuasan akan keleluasaan untuk memilih produk batik yang ditawarkan secara online, kepuasan layanan dapat meningkatkan niat untuk menggunakan media online untuk mencari motif baru produk batik, dapat meningkatkan pembelian berulang dalam berbelanja produk batik, dalam meningkatkan word of mouth orang terdekat supaya merasa kepuasan seperti yang dirasakan.

Hasil penelitian ini mendukung penelitian Thorsten et al. (2002). Kim (2007) menunjukkan 
bahwa kesuksesan teknologi informasi ditentukan oleh bagaimana pengembangan teknologi tersebut dapat memberikan kontribusi kepuasan kepada para pengguna teknologi secara individu maupun organisasi, sehingga dengan memberikan kontribusi positif kepada para penggunanya dapat mempengaruhi intensitas penggunaan teknologi tersebut yang ditunjukkan oleh semakin sering dan semakin lamanya menggunakan teknologi informasi.

Lin \& Hsieh (2007) membuktikan kepuasan menggunakan self service technology antara lain untuk membeli tiket pesawat terbang, menggunakan fasilitas perbankan dapat mempengaruhi intensitas untuk menggunakan kembali self service technology di masa mendatang. Konsumen yang loyal juga akan mendatangkan konsumen-konsumen baru karena konsumen yang loyal akan menyampaikan rekomendasi dari mulut ke mulut yang positif kepada orang lain.

\section{SIMPULAN DAN SARAN}

Hasil-hasil estimasi hubungan kausal dari penggunaan strategi CRM yang berdasarkan TAM menunjukkan bahwa TAM melalui variabel keyakinan akan kemudahan dan keyakinan akan kemanfaatan dapat menjadikan konsumen melakukan pembelian berulang, karena konsumen merasa puas. Jika dikaitkan dengan TAM yang dikembangkan oleh Davis (1989), hasil penelitian ini memberikan kontribusi pada pengembangan TAM. Kontribusi yang diberikan adalah pada awalnya TAM bertujuan untuk menjelaskan hubungan kausal antara keyakinan, sikap pengguna, niat dan perilaku aktual.

Hasil penelitian ini juga menunjukkan bahwa MO dipengaruhi oleh TAM. Hasil penelitian ini mengembangkan hasil penelitian Thorsten et al. (2002), Yen et al. (2010) dan Tracey \& O'Brien (2010). Penggunaan teknologi untuk penjualan online dengan kemudahan dan kemanfaatannya dapat digunakan untuk meningkatkan keuntungan yang diterima oleh konsumen hasil pembinaan hubungan jangka panjang sekaligus dapat digunakan juga untuk meningkatkan kepuasan konsumen dan pembelian ulang produk secara online.

Didasarkan pada hasil penelitian Hong et al. (2006), Hwang \& Kim (2007), dan Lin \& Sun (2009), dapat diargumentasikan bahwa TAM berpengaruh terhadap MO. Berdasarkan hasil penelitian tersebut dapat diargumentasikan bahwa melalui keyakinan akan kemudahan dan kemanfaatan TAM dapat digunakan untuk meningkatkan kepuasan konsumen dan niat membeli kembali.
Berdasarkan hasil-hasil penelitian ini, ditunjukkan bahwa model secara keseluruhan memenuhi syarat dan dapat diterima. Dengan demikian, beberapa implikasi kebijakan yang dapat diturunkan adalah sebagai berikut:

1. Dalam meningkatkan keyakinan akan kemudahan maka desain web lebih diarahkan pada bagaimana caranya supaya konsumen mendapat kemudahan dalam berbelanja online produk batik. Hal ini dapat dilakukan dengan memberikan kejelasan prosedur belanja yang ditampilkan di dalam website mulai dari memilih barang, melihat harga sampai memasukkan barang yang akan dibeli ke dalam keranjang belanja. Menampilkan foto sekaligus harga pada setiap produk yang dijual, sehingga konsumen lebih mudah mempertimbangkan harga dengan motif batik yang ditampilkan untuk memperoleh harga yang diharapkan dengan kualitas produk yang bagus.

2. Kemanfaatan berbelanja online dapat dibangun dengan cara memberikan sejarah layanan sehingga tidak terjadi pertanyaan yang berulangkali, misal: motif, warna yang disuka, dan sistem pembayaran.

3. Kepuasan konsumen dalam berbelanja online dapat ditingkatkan dengan keleluasaan dalam melakukan pilihan produk, dan pengiriman tepat waktu.

Namun demikian, penelitian ini tidak terlepas dari beberapa keterbatasan. Jadi, penelitian-penelitian di masa mendatang dapat diarahkan untuk mengisi gap ini. Berikut ini beberapa keterbatasan penelitian dan masukan untuk penelitian selanjutnya:

1. Hasil penelitian ini mengembangkan model konseptual baru model TAM-MO. TAM pada penelitian ini tidak menyertakan variabel eksternal sebagai mediator dari dampak karakteristik sistem dan kualitas output yang dirasakan pada perilaku penggunaan.

2. Hasil penelitian ini memberikan temuan implementasi model CRM melalui tiga ruang lingkup kajian, yaitu operasional, strategis dan analitis. Namun penelitian ini belum mengkaji secara empirik ketiga lingkup kajian tersebut pada TAMMO. Agenda penelitian mendatang dapat dilakukan penelitian untuk menjelaskan secara empirik ruang lingkup kajian CRM, yaitu operasional, strategis, dan analitis terhadap TAM-MO.

3. Urgensi penelitian berkaitan dengan perbandingan pemasaran secara online dan secara konvensional (offline). 


\section{DAFTAR REFERENSI}

Brown, S. A. 2000. Customer Relationship Management: A Strategic Imperative in the World of eBusiness. Toronto: John Willey and Sons.

Celuch, K., Goodwin, S., \& Taylor, S. A. 2007. Understanding Small Scale Industrial User Internet Purchase and Information Management Intentions. Industrial Marketing Management, 36(1): 211-221.

Cheng, E., Lam, D., \& Andy Y. 2005. Adoption of Internet Banking: An Empirical Study in Hongkong. Working Paper, The Hong Kong Polytechnic University.

Chin, W. W. \& Todd, P. A. 1995. On the Use, Usefulness, and Ease of Use of Structural Equation Modeling in MIS Research: A Note of Caution. MIS Quart., 19(2): 237246

Davis, F. D. 1989. Perceived Usefullness, Perceived Ease of Use of Information Technology. Management Information System Quarterly, 13 (3): 319-340.

Dutka, A. 1995. AMA Handbook of Customer Satisfaction. New York: AMA.

Gefen, D., Karahanna, E., \& Straub, D. W. 2003. Trust and TAM in Online Shopping: An Integrated Model. Management Information System Quarterly, 27(1): 51-90.

Grace, T. R., Lin, \& Chia-Chi, S. 2009. Factors Influencing Satisfaction and Loyalty in Online Shopping: An Integrated Model. Online Information Review, 33(3): 458-475.

Hair, J. F., Anderson, R. E., Tatham, R. L., \& Black, W. C. 1998. Multivariate Analysis. Fifth Edition. New Jersey: Prentice-Hall.

Hong, J., Thong, J., \& Yan, K. T. 2006. Understanding Continued Information Technology Usage Behavior: A Comparison of Three Models in the Context of Mobile Internet, Decision Support Systems, 42(3): 1819-1834.

Hwang, Y. \& Kim, D. J. 2007. Customer SelfService Systems: The Effects of Perceived Web Quality with Service Contents on Enjoyment, Anxiety, and E-Trust. Decision Support Systems, 43: 746-760.

Kim, C. 2007. An Empirical Investigation into the Utilization-Based Information Technology Success Model. Journal of Information Technology, 22(1): 152-160.

Kotler, P. 2002. Manajemen Pemasaran Edisi Milenium. Jakarta: PT Prehalindo.
Lin, G. T. \& Sun, C.C. 2009. Factors Influencing Satisfaction and Loyalty in Online Shopping: An Integrated Model. Online Inform. Rev., 33: 458-475.

Lin, J. S. C. \& Hsieh, P. L. 2007. The Influence of Technology Readiness on Satisfaction and Behavioral Intentions toward SelfService Technologies. Computers in Human Behavior, 23(3): 1597-1615.

Rao, S. \& Troshani, I. 2007. A Conceptual Framework and Propositions for the Acceptance of Mobile Services. Journal of Theoretical and Applied Electronic Commerce Research, 2(2): 61-73.

Rebecca, Y., Ju, H., \& Gwinner, K. P. 2003. Internet Retail Customer Loyalty. International Journal of Service Industry Management, 14(5): 483-500.

Rose, J. \& Fogarty, G. 2006. Determinants of Perceived Usefulness and Perceived of Easy of Use in the Technology Acceptance Model: Senior Consumers Adoption of Self Service Banking Technologies. Paper was presented at the second Biennial Conference of the Academy of World Business, Marketing and Management Development: Business Across Borders in the 21st Century, France, 10-13 July 2006.

Srivastava, S. \& Fahey. 1999. Market Based Assets and Shareholder Value: A Framework for Analysis. Journal of Marketing, 62(1): 2-18.

Thompson, R. \& Howell, H. 1991. Personal Computing: Toward a Conceptual Model of Utilization. Management Information System Quarterly, 15(1): 125:143.

Thorsten, K., Gwinner, P., \& Dwayne, G. 2002. Understanding Relationship Marketing Outcomes an Integration of Relational Benefits and Relationship Quality. Journal of Service Research, 4(3): 230-247.

Tracey, S. D. \& O'Brien, T. K. 2010. Does Experience Matter? Differences in Relationship Benefits, Satisfaction, Trust, Commitment and Loyalty for Novice and Experienced Service Users. European Journal of Marketing, 44 (9/10): 1528-1552.

Usmara. 2003. Strategi Baru Manajemen Pemasaran. Yogyakarta: PT. Amara Books.

Wynne, C. W. \& Peter, T. 1991. The Use Usefullness, Ease of Use of Structural Equation Modeling in MIS Research. Management Information System Quarterly, 16(2): 21-33.

Yen, D. C., Wu, C. S., Cheng, F. F., \& Huang, Y. W. 2010. Determinants of Users' Intention to Adopt Wireless Technology: An Empirical Study by 
Integrating TTF with TAM. Computers in Zigmund. 1997. Exploring Marketing Research. New Human Behavior, 26(5): 906-915. York: Dryden Press. 